\title{
Assessment of the Level of Compliance of Petroleum Filling Stations to Development Control Standards on Land Space/Size and Setbacks in Anambra State.
}

\author{
Ulasi, J. O. ${ }^{1}$ Uwadiegwu, B. O ${ }^{2}$.and C.O.Okoye ${ }^{2}$ \\ 1 National Population Commission, Anambra State. \\ 2 Department of Environmental Management, Nnamdi AzikiweUniversity, Awka \\ Corresponding Authors's Email: ulasijoj@yahoo.com. Phone:+2348033331992
}

\begin{abstract}
Sequel to the loss of lives and properties with other attendant negative socio-economic effects of non-compliance to development control standards, this study was conceived with the aim of assessing the level of compliance of petroleum filling stations to development control standards on land space/size and setbacks in Anambra State. The study adopted the survey research design and field measurement. There were actual field measurements of the filling stations under study as well as the use of imageries of the study areas to identify these filling stations and measure their level of compliance to set standards for distances and location. 270 filling stations which is about $31 \%$ of the total number of filling stations were sampled. Arc GIS 10.1 software was utilized to measure the distances between the sited Petroleum Filling Stations and the roads with the help of a computer system. The imagery used was Quickbird ( $0.5 \mathrm{~m}$ resolution) and Ikonos (1m resolution). The age ranges between 2015 and 2018. The Software used was ESRI ArcGIS 10.3, GIS Software. It has a measuring tool which was used to measure the distance. The Imagery were added using the 'Add' tool. It was then displayed (re-projected) on Projected Coordinate System (UTM, WGS 1984, Zone 32) for accuracy. It was found that the overall level of compliance to land space/size and setback standards is 44.1 percent across the filling stations in Anambra State. That is to say that only 44.1 percent of the PFSs in Anambra State complied with the land space/size and setback standards of building filling stations. Also that there is significant difference between the distances of the filling stations sampled from the road and the set standards for setback. The study thus recommends that: the law should empower the planning officer(s) to prosecute all cases of illegal developments and plans by non-planners without the planners approval should be subjected to prosecution as well. There is great need for public participation as the owners of these lands can join hands to say that a wrongly sited structure cannot be. Campaign should be mounted to conscientize the filling station owners and other developers of the dangers of non-compliance to set standards. Open punishment should be given to all defaulters to the set standards and corrupt officials of the enforcement agencies/bodies for others to learn their lessons. Finally, there should be proper planning to accommodate future expansion of roads.
\end{abstract}

KEYWORDS: Development Control Standards, Compliance, Land Space/Size, Setbacks, Petroleum Filling Stations.

DOI: $10.7176 / \mathrm{CER} / 12-2-10$

Publication date: February $29^{\text {th }} 2020$

\section{$1.0 \quad$ INTRODUCTION}

\subsection{BACKGROUND TO THE STUDY}

The deplorable state of the physical environment particularly in the urban centers, today is a major global issue, with greater concern in the developing countries like Nigeria (Ogundele, Ayo, Odewumi, and Aigbe, 2011), making development control a necessity. The regulatory authorities have turned a blind eye to the numerous contraventions of town planning laws or development control standards being committed by some developers in their precinct. In major cities within the country, state capitals and business centres, similar abuses are common (Oduwaye, 2009). The entire land-use is fast changing in character and landscape precipitated by incompatible development (Aluko, 2000; 2011). 
The challenges of non-compliance is staring in the face.Lekwotet al (2013) revealed the lawlessness unplanned physical development and haphazard implementation of developmental projects in many places like in Port Harcourt as reported by Kio-Lawson, Duru, John and Eebee (2016); Zaria as highlighted by Kawu, Ahmed, and Usman (2012); Lagos as stated by Oduwaye (2009); the case of Anambra State is glaring with a lot of structures like Petroleum Filling Stations being sited where they cause obstructions to traffic and endanger peoples life. The case of indiscriminate siting of filing stations without complying to standards set by the regulatory agencies mentioned earlier is pronounced and increasing by the day. The environmental implications and dangers posed to man by these actions are imminent. The solution to this problem becomes expedient to be sought by research in order to actualize positive results in the course of enforcement and to ensure that laws satisfying both private and public needs are harmonized into the present conditions in development control. To achieve a formidable solution one needs to establish level non-compliance, hence this study.

\subsection{STATEMENT OF THE PROBLEM}

It has been the practice for the Government(s) to wake up one day and start demolishing houses/structures as a solution to a problem they created (we created ourselves) and or a problem which could have been avoided by heeding to development control standards. For instance, Kio-Lawson et al (2016) reported that in the city of Port Harcourt while the Ministry of Urban Development had succeeded in demolishing over 4,000 make shift shops that had defaced the city between 2011 and 2013, more than 1,000 new ones had sprang up in the last twelve months having the approval of the local government councils. For the local government councils, it was another source of revenue generation. The local government councils believed that it is within their statutory power to manage the cities; therefore they have the power to approve the erection of make-shift shops for residents. Some members of the public interviewed in the four sample cities by Kio-Lawson et al (2016), claimed that "the location of fuel stations indiscriminately in the heart of residential areas, the sitting of electricity transformers and refuse dumps in our cities without any regard for the safety of residence, goes a long way to question the existence and effectiveness of the town planning laws or agencies.

The loss of lives and properties with their attendant negative socio-economic effects of non-compliance to development control standards cannot be over emphasized. The recent fire incident on Wednesday 15 th of February 2017 at DMGS junction Onitsha with great cost being a clear example as the fire outbreak ravaged more than would have been if development control standards had been observed in such area. The situation in Onitsha is also evident in other major cities of Anambra State like Awka and Nnewi with constant population increase. On Friday the $24^{\text {th }}$ of February 2017, a filling station sited adjacent to the tipper park in Eke Nibo Market in Awka South Local Government Area of Anambra State, due to lack of space had an offloading tanker filled with petrol got inflamed while trying to turn and enter the filling station. Thanks to God Almighty for the emergency intervention of the State Fire service, otherwise the entire village and houses around would have been consumed in the flame. It only resulted in the burnt tanker blocking the road for about two days before its removal. The attendant externality was delay in travel time by the road users due to the absence of a major alternative route. This issue of delay in travel time is now normal in our cities within and outside Anambra State as some of these filling stations are sited at locations with limited space such that for them to offload their products the traffic has to be delayed sometimes for hours. The indiscriminate sitting of filling stations and other commercial structures without considering the set standards is the order of the day as some of the enforcement agencies now take bribe for approvals and allow the filling stations to do whatever they wish leaving defaulters to carry on with their activities without any punishment. The implementation of development control standards is thus haphazardly done and only in some cases within the state. Although there has not been concrete empirical work to prove this, but reconnaissance survey of some of the filling stations supports this speculation.

Upon all the dangers of indiscriminate citing of petroleum filling stations without compliance to set standards and the loss of lives and properties evident in Anambra State, some of which were highlighted above, the earlier researchers were unable to tackle this issue within the state. Earlier researchers did a lot of work on the issue of compliance to set standards by petroleum filling stations, like the works of Olusegun et al (2011); Mohammed et al (2014); Njoku\&Alagbe (2015); Murtala (2015); Thomas et al (2016); Odipeet al (2018); Lekwortet al (2013); Bogoro and Nghalmi (2014); Philip (2007); and Kio-Lawson et al, (2016) among others, but they were unable to evaluate the level of compliance of these petroleum filling stations to the set standards by ANSPPB, NESREA and DPR being the main regulatory bodies for Petroleum Filling Station establishment within the state. This tried to handle this from the side of land space size and setbacks. 


\subsection{AIM AND OBJECTIVES}

The aim of this study is to assess the level of compliance of petroleum filling stations to development control standards on land space/size and setbacks in Anambra State.

To achieve this aim the following objectives were pursued:

1. to ascertain the set standards on land space/size and setbacks in Anambra State.

2. to ascertain the level of compliance of petroleum filling stations with land space/size and setback standards,

3. to make recommendations on what needs to be done to improve compliance to these set standards.

\section{Hypothesis}

Ho: There is no significant difference between the distances of the filling stations sampled from the road and the set standards for setback.

\subsection{LITERATURE REVIEW}

In line with the aim of this study, the following literature were reviewed:

Ujjwal and Sokhi (2006) applied GIS for petrol station vulnerability assessment in New Delhi, India. In their study land uses within the $200 \mathrm{~m}$ radius from each filling station were identified using high resolution Ikonos image and coordinate of the station were obtained using GPS. Stations were categorized into vulnerability classes on the bases of the use, density and population with 200 meter buffers. Nwanjo and Ojiako (2007) investigate the potential health hazards of petrol stations on attendants in Owerri, Nigeria. Attendants from twenty filling stations were assessed in the area and another twenty that were not exposed to its vapour were used as control. The result show a significant increase in the activities of alkaline phosphatase, analine and aspartate amino transfer asses for those exposed to petrol vapour from 6-10 years. Also the concentrations of serum urea, creatinine and urinary protein for those exposed to petrol vapour were significant based on the study. The study concluded that these effects are directly related to the duration of the exposure. However the study did not look at the role of distance in determining the concentration those chemical which may give another interesting picture, since not only attendants are exposed to petrol vapour, but also the stations ${ }^{\text {ee }}$ neighbor.

Ioj and Tudor (2011) examined the temporal changes in proximity of residential land use to filling stations in Bucharest suburban, Romania. Coordinates of the stations were obtained using GPS, aerial photographs and google earth imageries were used to digitize the residential areas. Buffer zones were created in map to see the encroachments of the residential areas. The results of the study revealed that 21 gas stations are located in residential areas and 39 gas stations are located in non-residential area. There are 10 gas stations (half of the total of 21) located in residential areas. The study thus concluded that there is high congestion of the gas stations in the residential area, although distance of filling stations to other conflicting land-use like public buildings, hospitals and the likes were not analyze by the study.

Olusegun, Folakemi, Omotayo\&Afolabi (2011), conducted an assessment of Safety Practices in Filling Stations in Ile-Ife, South Western Nigeria. In order to determine the level of awareness of hazards and safety measures among filling station attendants and assess the prevailing safety practices in filling stations in Ile-Ife, they adopted a descriptive cross-sectional study in which data was collected using an interviewer-administered questionnaire and an observational checklist. The collated data was analyzed using the SPSS version 16 software and discrete variables presented using tables and charts. Fisher's exact test was used to test association with level of significance set at $5 \%$. It was found that $94 \%$ of the respondents were aware of safety measures with fire extinguisher being the most common safety measure known (54\%). Fire hazard was the most common hazard known (94\%). Setbacks from the road and residential areas were less than 30 metres in $90 \%$ of the filling stations and stations owned by conglomerates had better safety measures compared to those owned by independent private marketers. They therefore called for the governmental and non-governmental agencies in-charge of regulations to ensure that proper measures are taken to enforce better compliance.

Khahro,Abd Nassir Matorib, Imtiaz\&Talpurb (2013), conducted a study in Ipoh, Perak, Malaysia with attention focused on analyzing the viable land parcels for installing new Petroleum Filling Stations. The geospatial data was collected from Mapping and Surveying Department of Ipoh. The standards used in practice for the site selection for Petroleum Filling Station were collected from City Planning Department, Ipoh. A set of questionnaire was also designed to get the stakeholders opinion regarding the site selection of the Petroleum Filling Stations. Analytic 
Hierarchy Process (AHP) was used as a Multi-Criteria Decision Making (MCDM) technique. Expert Choice (EC) was used to analyze the qualitative results. At the end, to achieve the main objective of the research, the spatial data was used to identify the suitable land parcels for installing new Petroleum Filling Stations using GIS. The responses from the public were analyzed to generate the land suitability map for Petroleum Filling Stations location and to validate the final land suitability map for Petroleum Filling Station, the overlay technique was adopted. The data layer of existing Petroleum Filling Stations was generated by using the coordinates. The coordinates were collected from the online available source provided by the Malaysian Geospatial Data Infrastructure. The coordinates were validated by using the hand Global Positioning System (GPS). It was found that majority of the Petroleum Filling Stations did not comply with the set standards on location and distances from residential houses which were the criteria for establishing new Petroleum Filling Stations.

A similar GIS based Analysis of the location of Petroleum Filling Stations in Kano Metropolitan Area in northern Nigeria was conducted by Mohammed, Musa \& Jeb (2014), to establish the compliance of Petroleum Filling Station entrepreneurs to the Physical Planning Standards set by the Department of Petroleum Resources (DPR) (2007). The results produced some unique and significant revelation on the non-compliance of some of the Petroleum Filling Stations to the standards. For instance, it was revealed that, only eight (8) stations (4\%) out of 192 stations did not meet the criteria of 15 meters minimum distance from road. Njoku and Alagbe (2015) also highlighted on some of the illegal location of Petroleum Filling Stations in Oyo State using GIS to assess suitability of Petroleum Filling Stations.

Njoku\&Alagbe (2015) Site Suitability Assessment of Petroleum Filling Stations (PFSs) in Oyo Town, Oyo State, Nigeria: a Geographic Information Systems (GIS) Approach. In this study, a GIS was developed for PFS site suitability assessment. The standard criteria set for PFS siting by Oyo State Urban and Regional Planning Board (OSURPB) and the Nigerian Department of Petroleum Resources (DPR) were considered. The DPR criteria were incorporated to assess possible lapses in the local standards. The study is multi-dimensional, incorporating suitability, proximity and spatial statistical techniques. The results showed that, out of the 113 PFSs in the area, only 3 , representing just 2.654 percent are in high suitability zone, 6 PFSs (5.309 percent) in in medium as well low and 98 stations ( 86.725 percent) in very low suitability zone. Considering the OSURPB criterion, 76 PFSs are at unacceptable distances to residential land use and as much as 102 PFSs considering the DPR criterion. Also, assessing the size of PFSs, 41 stations (39 percent) have the standard land area while 69 PFSs (61 percent) were deficient. Furthermore, only 6 stations, representing 5 percent of PFSs in the area have their dispensing pumps at least $15 \mathrm{~m}$ off the road. More so, the assessment of the spatial pattern of PFSs in the area showed that the distribution of petrol stations are very clustered with less than 1 percent likelihood that the clustered pattern could be a result of random chance. It was concluded that most PFSs in Oyo town, considering both local and national siting standards were not suitably sited and also contravene planning standards. Also, the substandard requirements proliferated by the local planning authorities, who are defiant of the national standards undoubtedly increases the threats on the health and safety of users and residents in the vicinity of these PFSs.

Arokoyu, Ogoro, and Jochebed (2015) did an investigation on the location of Petroleum Filling Stations and compliance to minimum environmental standard requirements in Obio-Akpor Local Government, Rivers State of Nigeria. The study examined the proliferation of Petroleum Filling Stations in relation to the minimum environmental safety requirements by the Department of Petroleum Resources (DPR) that distance from the edge of the road to the nearest pump and from the next Petroleum Filling Station should not be less than 15 and 400 meters respectively. The Global Positioning System (GPS) was used to acquire the coordinates of each filling station in the study area and then imported to the Arc-GIS 9.3 software environment. Distances between filling stations from the road and from each other were determined using the Arc-GIS 9.3 measurement tool alongside buffering analysis in respect to their coordinates. The $\mathrm{Z}$ ratio analytical technique was used to examine the conformity of Petroleum Filling Stations to the required distance of $400 \mathrm{~m}$ and $15 \mathrm{~m}$ from each other and from the road respectively as stipulated by DPR amendment decree 37 of 1997. Findings from the Z ratio analysis at 152 degree of freedom and $95 \%$ confidence level reveals that the Petroleum Filling Stations in the study area neither complied with the required distance of $400 \mathrm{~m}$ apart nor complied with the required distance of $15 \mathrm{~m}$ from the road. Thus, the study recommends, among others, the need for the regulatory agencies like DPR, to improve their capacity in enforcing the compliance of Petroleum Filling Stations with laid down regulations.

Murtala (2015) analysed the location of filling stations in Kano Metropolis and their compliance to the physical planning standards set by Department of Petroleum Resource (DPR) and Kano Urban Planning and Development Agency (KNUPDA) using GIS. Names and street addresses of the filling stations were obtained from the Department Petroleum Resource (DPR) Kano. Global positioning System Garmin 76X GPS was used to capture the locations of the filling stations. The Quickbird imagery, street map, and boundary map were obtained from the 
Kano State Ministry of Land and Physical planning and then imported to Arc-map environment of Arc-GIS 10, integrated and geo-referenced to the same coordinate system. The findings revealed that there are 214 filling stations located along the 43 roads in the study area, of which $69 \%$ are owned by independent marketers, $26 \%$ owned by Major Marketers and 5\% owned by the NNPC. There is significant correlation between the number of filling stations and the road hierarchy. While Zaria, Maiduguri and Katsina roads (all major roads) have the highest number of filling stations, the access roads like Sabo BakinZuwo and Zungeru roads have highest density of filling station per $\mathrm{km}$. The overall pattern of the location of the filling stations in the area is clustered, and there is significant difference between the pattern and random pattern at both 95 and $99 \%$ level of significance. The major factors governing the location of filling stations are the traffic flow, exit site from the city and closeness to motorpark. Most of the filling stations satisfied the minimum requirement of 15 metres distance from the road $(96 \%)$. Equally $98 \%$ of the filling stations met the minimum distance of 100 meter from the health care facilities. However many stations had not meet the criteria of 400 meter minimum distance to other stations where located on same road side and when not separated by any road or street. The research recommends that the regulatory agencies should take appropriate which ensure that filling stations operators comply with the standards.

A study carried out in Maiduguri and Jere, Borno State, Nigeria, on the dangers facing the workers in the petrol stations and the residents living nearby the petrol stations as they have in one time or the other suffered various health effects as a result of working in petrol stations or being close to them by Mshelia, Abdullahi\&Dawha (2015) showed that, respiratory problems (diseases) had the highest percent of $38.05 \%$. This by implication means, it was the most prevalent health problems affecting both the workers and some of the residents as a result of the inhalation of fuel contaminated air. However, skin and sight problems alongside other health complications were also issues of concern. If the situations continue thereafter, such could lead to narcotics effects with symptoms including headache, nausea, dizziness and mental confusion (Mshelia, et al, 2015). From the result obtained, only $26 \%$ were located in conformity with the standards and guidelines. The study also revealed that some of the petrol stations were separated by a wall or narrow path. One significant revelation from the study was that, some of the petrol stations were located much earlier before environmental guidelines and regulations were formulated. Similarly, some of the residential houses were later developed close to Petroleum Filling Stations. In other words, urban planners also fail to implement physical development control measures to restrain potential landlords from building living houses close to Petroleum Filling Stations. This was in accordance to the position of Afolabi, Olajide\&Omotayo (2011).

Another study by Hamid, Iman, Suriatini\& Martin (2009) studied site potentiality for petrol station business based on traffic volume counts using a regression and Geographic Information System (GIS) based spatial system. The authors stressed that, site potentiality is an important factor that influences business success of a petrol station which relies on customer visits. A very important note on this issue by Kearny (1998) cited in Thomas et al (2016) disclosed that, it was empirically found in the United States of America that, site location was the primary factor for drivers to choose a petrol station but this is not the case here in Nigeria being capitalist to an extreme.

Motivated by the sporadic emergence of Petroleum Filling Stations within the City of Kitwe in Zambia which raised a lot of questions like: "What are the locational determinants for filling stations in urban areas in Zambia?" What is the public's perception on location of filling stations in the City of Kitwe? What are the possible factors that influence filling stations' locations in Kitwe? Are filling stations located according to established planning standards, guidelines and regulations in the City of Kitwe? These are questions that require empirical investigations in view of the possible inflammatory consequences of the service. Thomas, Chanda\& Blessings (2016) conducted an investigation on the Perceptions of the Public on Location of Filling Stations in the City of Kitwe in Zambia. This exploratory study applied a cross-sectional descriptive research design to find answers to the research questions and to validate the following hypotheses: Environmental Impact Assessment (EIA) Criteria is positively related to the location of filling stations in Kitwe; Entrepreneurs preferential location choices is positively related to location of filling stations; and Planning principles, standards and regulations positively influence locations of filling stations in the City of Kitwe. The t-test statistics was used to validate the hypotheses. The main finding was that, many of the Petroleum Filling Stations were wrongly located and their location are influenced by choices made by service station entrepreneurs who are more interested in areas of market flow not considering the environmental implications.

Odipe, Lawal, Adio, Karani, \&Sawyerr (2018), conducted a GIS-based location analyses of Retail Petrol Stations in Ilorin, Kwara State, Nigeria. The data for this study were obtained through field surveys; with the coordinates of the stations acquired using handheld Global Positioning System (GPS) device, and other information gotten through administration of questionnaire to owners and workers in each petrol station. Spatial analysis was done using the Arc-GIS 10.4 by ESRI on an Open Street Map database, while simple descriptive analysis used Excel 
2016 package. It was found that 297 retail petrol stations were in Ilorin, of which $112(38 \%)$ of these stations were above 15 years of age, $224(75 \%)$ of the stations were functioning as at the time of this study while $73(25 \%)$ were either abandoned or under construction. The number of dispensing pumps per station varies but $215(72 \%)$ stations has 4-6 operating pumps. Most of the stations were found at close proximities to public premises such that $10(3 \%)$ were in close proximities to school, $226(76 \%)$ to shops, $192(65 \%)$ to residential houses and $11(4 \%)$ were close to hospitals. The research concludes that retail petrol stations are highly congested within the metropolis forming cluster pattern which poses a great threat to the densely populated region of the town and is not in conformity with the set standards for establishing these Petroleum Filling Stations.

\subsection{STUDY AREA}

Anambra State is one of the states in Nigeria within latitudes $5^{0} 40 \mathrm{~N}$ and $6^{0} 48 \mathrm{~N}$ and longitudes $6^{0} 35 \mathrm{E}$ and $7^{0}$ 30 E. it is bounded by seven states in Nigeria which includes: Enugu, Kogi, Edo, Delta, Rivers, Imo and Abia States. Figure 1 is the map of Nigeria showing Anambra State.

Fig 1.1: Nigeria Showing Anambra State (Source: Excel Research Centre, Awka)

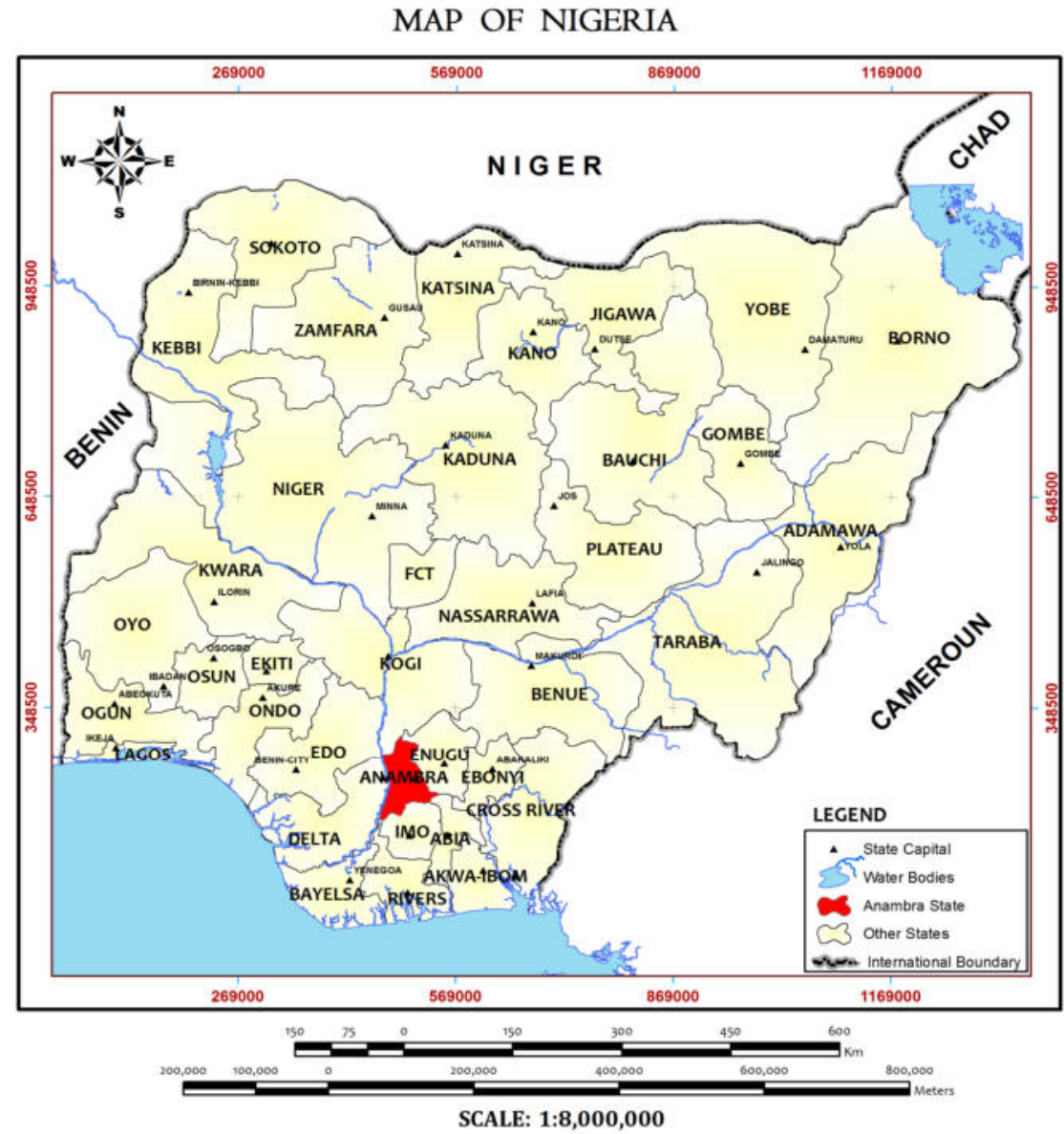

Anambra is the eight most populated state in the Federal Republic of Nigeria and the second most densely populated state in Nigeria after Lagos state (N.P.C, 2006). The stretch of more than $45 \mathrm{~km}$ between Oba and Amorka contains a cluster of numerous thickly populated villages and small towns giving the area an estimated average density of $1,500-2,000$ persons per square kilometer (UN- Habitat.2009).

\subsection{METHODOLOGY}

This study adopted the survey research design and field measurement. There were actual field measurements of the filling stations under study as well as the use of imageries of the study areas to identify these filling stations and measure their level of compliance to set standards for distances and location of PFSs. 
The population of the filling stations in Anambra State as obtained from ANSPPB is 855, but the number of filling stations per local government area; vary widely. Here, purposive and stratified random sampling techniques were adopted. Purposively Petroleum Filling Stations were selected for sampling from each of the local government areas for the reason of ensuring wide coverage across the Study Area. The stratified random sampling technique is applied in separating the filling stations in each LGA into those on the local roads, state roads and federal roads and ensuring that a percentage of the sample size for each LGA is taken from each stratum.

Applying the Taro Yamaine's formula, the number of filling station selected across the Study Area was 269.3 that is approximately 270 filling stations which is about $31 \%$ of the total number of filling stations. For the purpose of proper representation, $31 \%$ of the number of filling stations in each LGA were sampled.

The instruments of data collection for this study includes: field observation-measurements and Arc-GIS measurements. Arc GIS 10.1 software was utilized to measure the distances between the sited Petroleum Filling Stations and the roads with the help of a computer system. Also after the digital measurement which utilizes imageries from remote sensing, there was proper field measurements with meter tapes and GPS (ground-truthing) and this was juxtaposed with what was gotten from the Arc GIS measurement and finally compared with the set standards established for the establishment of PFSs.

The imagery used was Quickbird ( $0.5 \mathrm{~m}$ resolution) and Ikonos ( $1 \mathrm{~m}$ resolution). The age ranges between 2015 and 2018. The Software used was ESRI ArcGIS 10.3, GIS Software. It has a measuring tool which was used to measure the distance. The Imagery were added using the 'Add' tool. It was then displayed (re-projected) on Projected Coordinate System (UTM, WGS 1984, Zone 32) for accuracy. The measuring tool was then used to measure the distance. The measurement was done using planar option (plane), and Meters as the unit.

The Imagery were of Very High Resolution (VHR), and as such the Filling Stations were well displayed. The better option is Aerial Photograph which has a resolution of $0.25 \mathrm{~m}$, which is not available and will be very expensive to obtain considering the budget of this study. The Software (ArcGIS) is very robust and has various GIS capabilities. It has an array of Co-ordinate systems, and projects can be re-projected on-the-fly to any of the Co-ordinate systems.

\subsection{DISCUSSION OF RESULTS/FINDINGS}

To ascertain the level of compliance to land space/size and setback standards the percentage compliance was calculated as contained in table 1 .

Table 1: Land Space/Size and Setback Standard Measurements

\begin{tabular}{|l|l|l|l|}
\hline S/N & Compliance with Land Space/Size and Setback Standard & $\begin{array}{l}\text { NO. } \\
\text { Complied }\end{array}$ & $\begin{array}{l}\text { \% } \\
\text { Complied }\end{array}$ \\
\hline 1 & Minimum plot size of fuel station shall be 35m x35m & 76 & 28.1 \\
\hline 2 & Maximum plot coverage is 60\% & 136 & 50.4 \\
\hline 3 & $\begin{array}{l}\text { Mini vehicle manoeuvring area is } 1100 \mathrm{~m}^{2} \text { with a minimum frontage of } \\
\text { 9m facing the primary street }\end{array}$ & 72 & 26.7 \\
\hline 4 & $\begin{array}{l}\text { Buildings inside the station must be at a minimum of 12m from the road } \\
\text { property boundary. }\end{array}$ & 109 & 40.4 \\
\hline 5 & $\begin{array}{l}\text { Petrol pumps must be located at a minimum of 30m from residential } \\
\text { buildings. }\end{array}$ & 161 & 59.7 \\
\hline 6 & There should be a minimum distance of 10m UST and dispensing pumps & 110 & 40.7 \\
\hline 7 & $\begin{array}{l}\text { There shall be a minimum of 3 dispensing pumps (one for each of the } \\
\text { petrol, diesel and kerosene) }\end{array}$ & 105 & 38.9 \\
\hline 8 & Minimum set back of Petroleum Filling Stations to a 330kv line is 32m & 193 & 71.5 \\
\hline 9 & $\begin{array}{l}\text { Minimum set back of Petroleum Filling Stations to a 66kv power line is } \\
8 \mathrm{~m}\end{array}$ & 127 & 40.0 \\
\hline 10 & Minimum set back of Petroleum Filling Stations to a 132kv line is 16m & 119 & 44.1 \\
\hline & \multicolumn{2}{|c|}{ Average Percentage } & $\mathbf{4 4 . 1}$ \\
\hline
\end{tabular}

Source: Author's Computation (2019).

Table 1 contains the information about the land space/size and setback standards measures which are to be observed before a filling station is to be built. The requirement has it that the minimum plot size should be $35 \mathrm{~m}$ 
by $35 \mathrm{~m}$, but the result shows that only 28.1 percent of the filling station owners observed this minimum requirement. Another requirement is that the maximum plot coverage should be $60 \%$, but only 50.4 percent of the filling stations were able to meet up with this; the rest didn't meet up. Coming to the standard of mini vehicle maneuvering area, according to the standard, this should be $1100 \mathrm{~m}^{2}$, but only 26.7 percent of the filling stations observed this; this shows a low level of compliance. Another standard is that buildings inside the station must be at a minimum of $12 \mathrm{~m}$ from the road property boundary, to this, only 40.4 percent of the filling stations complied. Only 59.7 percent of the filling stations were able to comply to the requirement of the petrol pumps being located at a minimum of $30 \mathrm{~m}$ from residential buildings; the rest didn't meet this requirement. The standard has it that there should be a minimum of $10 \mathrm{~m}$ UST and the dispensing pumps; it was only 40.7 percent of the respondents that observed this, the rest could not meet up with this expectation. 38.9 percent of the filling have a minimum of 3 dispensing pumps (one for each of petrol, diesel and kerosene), while 71.5 percent have their minimum setback of Petroleum Filling Stations to a $330 \mathrm{kv}$ line to be $32 \mathrm{~m}$ and 40 percent have their minimum setback of Petroleum Filling Stations to a $66 \mathrm{kv}$ power line to be $8 \mathrm{~m}$. Finally, 44.1 percent of the filling stations met the standard of minimum set back of Petroleum Filling Stations to a $132 \mathrm{kv}$ line being $16 \mathrm{~m}$.

The overall level of compliance to land space/size and setback standards is 44.1 percent across the filling stations in Anambra State. That is to say that only 44.1 percent of the PFSs in Anambra State complied with the land space/size and setback standards of building filling stations.

Hypothesis One: There is no significant difference between the distances of the filling stations sampled from the road and the set standards for setback.

Statistical Tool Used: One Sample T-Test

Reason for choice of Tool: One set of observations was compared with a known standard.

Degrees of Freedom: 269.

Decision Rule: Accept the null hypothesis if the $\mathrm{p}-\mathrm{value}$ is greater than or equal to 0.05 .

Test Proper: The result (output) of test is presented in tables 5.20a, 5.20b, 5.20c and 5.20d as shown.

Table 2: One-Sample Statistics for hypothesis one

\begin{tabular}{|l|r|r|r|r|}
\hline & \multicolumn{1}{|c|}{ N } & Mean & Std. Deviation & Std. Error Mean \\
\hline GIS distance from building to road & 270 & 16.4889 & 7.70156 & .46870 \\
GT distance from building to road & & & & \\
& 270 & 10.8556 & 5.19342 & .31606 \\
\hline
\end{tabular}

Source: Author's statistical analysis, 2019

Table 2 has the mean of the GIS and GT measurements of the filling stations from their buildings to road; the table shows that the mean of GIS measurements is 16.4889 while the mean with GT is 10.8556 .

Table 3: One-Sample Test for hypothesis one

\begin{tabular}{|c|c|c|c|c|c|c|}
\hline & \multicolumn{6}{|c|}{ Test Value $=12$} \\
\hline & \multirow[b]{2}{*}{$\mathrm{t}$} & \multirow[b]{2}{*}{$\mathrm{df}$} & \multirow{2}{*}{$\begin{array}{c}\text { Sig. } \\
\text { (2-tailed) }\end{array}$} & \multirow{2}{*}{$\begin{array}{c}\text { Mean } \\
\text { Difference }\end{array}$} & \multicolumn{2}{|c|}{$95 \%$ Confidence Interval of the Difference } \\
\hline & & & & & Lower & Upper \\
\hline $\begin{array}{l}\text { GIS distance from building } \\
\text { to road }\end{array}$ & 9.577 & 269 & .000 & 4.48889 & 3.5661 & 5.4117 \\
\hline $\begin{array}{l}\text { GT distance from building to } \\
\text { road }\end{array}$ & -3.621 & 269 & .000 & -1.14444 & -1.7667 & -.5222 \\
\hline
\end{tabular}

Source: Author's statistical analysis, 2019 
From table 3, it can be seen that the $\mathrm{p}$ - values of the test for GIS distance from building to road is 0.000 and also GT distance from building to road is 0.000 ; these values are lower than 0.05 . This implies that there is significant difference between distances of the filling stations sampled from the road and the set standards for setback. In the case of measurements with GIS, the distances are significantly above the minimum standard for setback (buildings inside the station must be at a minimum of $12 \mathrm{~m}$ ), but it is still within range. Then in the case of GT measurements, the distances are below the standard.

Table 4: One-Sample T-test Statistics for hypothesis one

\begin{tabular}{|l|c|r|r|r|}
\hline & $\mathrm{N}$ & Mean & Std. Deviation & \multicolumn{1}{c|}{ Std. Error Mean } \\
\hline GIS distance from last pump to road & 270 & 11.6778 & 4.44920 & .27077 \\
GT distance from last pump to road & 270 & 10.3667 & 4.38089 & .26661 \\
\hline
\end{tabular}

Source: Author's statistical analysis, 2019

Table 4 has the mean of the measurements with GIS and GT from the last pump to the road, the table shows that the mean when GIS was used is 11.6778 , while the mean with GT is 10.3667 . we then move to table $19 \mathrm{~d}$ to find out if these mean measurements are within standard or not.

Table 5: One-Sample Test for hypothesis one

\begin{tabular}{|c|c|c|c|c|c|c|}
\hline & \multicolumn{6}{|c|}{ Test Value $=15$} \\
\hline & \multirow[b]{2}{*}{$\mathrm{t}$} & \multirow[b]{2}{*}{ df } & \multirow{2}{*}{$\begin{array}{c}\text { Sig. } \\
\text { (2-tailed) }\end{array}$} & \multirow{2}{*}{$\begin{array}{c}\text { Mean } \\
\text { Difference }\end{array}$} & \multicolumn{2}{|c|}{$95 \%$ Confidence Interval of the Difference } \\
\hline & & & & & Lower & Upper \\
\hline $\begin{array}{l}\text { GIS distance from last pump } \\
\text { to road }\end{array}$ & -12.270 & 269 & .000 & -3.32222 & -3.8553 & -2.7891 \\
\hline $\begin{array}{l}\text { GT distance from last pump } \\
\text { to road }\end{array}$ & -17.379 & 269 & .000 & -4.63333 & -5.1582 & -4.1084 \\
\hline
\end{tabular}

Source: Author's statistical analysis, 2019

Table 5 contains the one sample t-test for checking whether the measurements of the distances from the last pump to the road are significantly the same with minimum setback standard, when GIS was used and when GT was done. The table shows that the $\mathrm{p}$-values for the tests are all 0.000 , less than 0.05 . The implication is that the averages of the measurements are significantly below the standard for setbacks (the distance from the road to the nearest pump must not be less than $15 \mathrm{~m}$ ); this means that the distance from the road to the nearest pump is significantly less than $15 \mathrm{~m}$.

Decision and Conclusion: Having gone through the various tables and the interpretations given in each, we therefore conclude that there is significant difference between the distances of the filling stations sampled from the road and the set standards for setback, thus rejecting the null hypothesis and accepting the alternative hypothesis.

\subsection{CONCLUSION AND RECOMMENDATION}

The overall level of compliance to land space/size and setback standards is about 44.1 percent across the filling stations in Anambra State. That is to say that only about 44.1 percent of the filling stations in Anambra State complied the land space/size and setback standards of building filling stations.

In line with the conclusion of this study, the following recommendations were made:

1. The law should empower the planning officer(s) to prosecute all cases of illegal developments and plans by non-planners without the planners approval should be subjected to prosecution as well.

2. There is great need for public participation as the owners of these lands can join hands to say that a wrongly sited structure cannot be.

3. Campaign should be mounted to conscientize the filling station owners and other developers of the dangers of non-compliance to set standards.

4. Open punishment should be given to all defaulters to the set standards for others to learn their lessons. 
5. There should be severe punishment of corrupt officials of the enforcement agencies/bodies.

6. There should be strict monitoring of the development control practices and agencies by the government.

7. There should be proper planning to accommodate future expansion of roads.

\section{REFERENCES}

Afolabi, O. T.; Olajide, F. O. \&Omotayo, S. K. (2011), Assessment of Safety Practices in Filling Stations in IleIfe, South Western Nigeria, Journal of Community Medicine and Primary Health Care, vol. 23. Nos. $1 \& 2$, Mar/Sept, pp. 9-15.

Aluko, O. (2011). Development Control in Lagos State: an Assessment of Public Compliance to Space Standards for Urban Development. International Multidisciplinary Journal, Ethiopia. 5 (5), 169-184. Serial No. 22.

Aluko, O. (2000). Development Control and Nigeria's New Civil Rule Programme.NITP Journal, 7, 79-88.

Arokoyu, S.; Ogoro, M. \&Jochebed, A. (2015).Petroleum Filling Stations' Location and Minimum Environmental Safety Requirements in ObioAkpor LGA, Nigeria.International Journal of Scientific Research and Innovative Technology. 2, 21-39. https://www.ijsrit.com/uploaded_all_files/3340225758_m4.pdf

Bogoro, A. G. \&Nghalmi, S. M. (2014). Knowledge, Attitude and Practices of Development Control InMellennium Quarters Yelwa, Bauchi, Nigeria. Quest Journal of Research in Environmental and Earth Sciences. 1 (1), 1-11. ISSN(Online) : 2348-2532 www.questjournals.org

Department of Petroleum Resource (DPR) (2007).Procedure Guide for Grant of and Approval to Construct and Operate Petroleum Products Retail Outlets. Issued by Department of Petroleum Resources,- Ministry of Petroleum Resources Nigeria.

Hamid, A. b., Iman. M. H., Suriatini, b. I. and Martin, R. bt., (2009), site Potentiality of petrol Stations Based on Traffic Counts, Malaysia Journal of Real Estate, vol. 4, No.1

Ioj, C.I., \& Tudor, C. A. (2011). Temporal analysis of incompatible land-use and land-cover: the proximity between residential areas and gas stations in Bucharest suburban area

Kawu, A. M., Ahmed, A. \&Usman, A. S. (2012).Learning from Tradition: Elements and Practice of Urban Development Control in Zaria City, Nigeria.American International Journal of Contemporary Research.2 (7), 205-213.

Khahro, S. H., Abd Nassir Matorib, A. N., Imtiaz, A. C, I, A., \&Talpurb. M. A. H. T. (2013), Land suitability analysis for installing new Petroleum Filling Stations using GIS. Fourth International Symposium on Infrastructure Engineering in Developing Countries, IEDC 2013, Vol. 77, pp. 28-36

Kio-Lawson, D.; Duru, M. N.; John, B. D. \&Eebee, A. L. (2016): The Challenge of Development Control in Nigerian Capital Cities- A Case of Some Selected Cities in the Niger Delta. Developing Country Studies. $6(2), 148-156$.

Lekwot, V. E.; Kyom, B. C. \&Balasom, M. K. (2013). The Nature, Scope and Dimensions Of Development Control, Tools And Machineries In Urban Planning In Nigeria. International Journal of Innovative Environmental Studies Research 1 (1):48-54.

Mohammed, M. U., Musa, I. J., \& Jeb, D.N., (2014), GIS-Based Analysis of the Location of Filling Stations in Metropolitan Kano against the Physical Planning Standards. American Journal of Engineering Research, vol. 3, No.9, pp. 147-158

Mshelia, M., Abdullahi, J. \&Dawha, E. (2015), Environmental Effects of Petrol Stations at Close Proximities to Residential Buildings in Maiduguri and Jere, Borno State, Nigeria, Vol. 20, No. 4, pp. 1-8.

Murtala, M. U. (2015). Location Analysis of Filling Stations in Kano Metropolis, Nigeria. A Dissertation Submitted to the School of Post Graduate Studies, Ahmadu Bello University, Zaria Nigeria. In Partial Fulfillment for the Award of Masters Degree in Remote Sensing and GIS Department of Geography Faculty of Science Ahmadu Bello University, Zaria Nigeria.

Njoku, C. \&Alagbe, A. O. (2015). Site Suitability Assessment of Petroleum Filling Stations (PFSs) in Oyo Town, Oyo State, Nigeria: a Geographic Information Systems (GIS) Approach..Journal of Environmental Science, Toxicology and Food Technology (IOSR-JESTFT). 9. 08-19. DOI: 10.9790/2402-091230819 
Nwanjo, H.U. \&Ojiako, O.A. (2007).Investigating the potential health hazards of the petrol station attendants in Owerri, Nigeria.Journal of Applied Science and Environmental Management.11 (2).

Odipe, O.; Lawal, A.; Adio, Z.; Karani, G. \&Sawyerr, H. (2018).GIS-Based Location Analyses of Retail Petrol Stations in Ilorin, Kwara State, Nigeria.International Journal of Scientific and Engineering Research.9, 790-794. https://www.researchgate.net/publication/330242228_GISBased_Location_Analyses_of_Retail_Petrol_Stations_in_Ilorin_Kwara_State_Nigeria

Oduwaye, L. (2009). "Challenges of Sustainable Physical Planning and Development in Metropolitan Lagos" Journal of Sustainable Development, 2(1), 159-171.

Ogundele, F. O., Ayo, O., Odewumi, S. G. \&Aigbe, G. O. (2011). Challenges and prospects of physical development control: A case study of Festac Town, Lagos, Nigeria. African Journal of Political Science and International Relations 5(4), 174-178.

Olusegun, A.; Folakemi, O.; Omotayo, S. \&Afolabi, O. (2011).Assessment of Safety Practices in Filling Stations in Ile-Ife, South Western Nigeria.Journal of Community Medicine and Primary Health Care.23, 9-15. https://www.researchgate.net/publication/271501044_Assessment_of_Safety_Practices_in_Filling_Sta tions_in_Ile-Ife_South_Western_Nigeria

Philip E (2007). Urban Planning and Development Control Regulations; Case study Kerala, ITPI Journal 4, 13 16 www.Itp:org.in

Thomas, K. T.; Chanda, S.; Blessings, C. (2016).Public Perceptions on Location of Filling Stations in the City of Kitwe in Zambia. Developing Country Studieswww.iiste.orgISSN 2224-607X (Paper) ISSN 2225-0565 (Online) Vol.6, No.6, 2016.

Ujjwal, S. \&Sokhi, B. S. (2006).GIS City Hazard Petrol Station Vicinity Vulnerability Assesment.GIM International 20 (8).

United Nations Human Settlements Programme UN-HABITAT; (2009): "Structure Plan for Awka and Satellite Towns”. Nairobi, Kenya. Website: http://www.unhabitat.org (UN-HABITAT, 2009). 